\title{
The epidemiology of acute occupational hand injuries treated in emergency departments in Foshan City, South China
}

\author{
Zhixin Wu, M.D., ${ }^{\text {* }}$ Yueming Guo, M.D., ${ }^{2}$ Junqing Gao, M.D., ${ }^{2}$ Jianyi Zhou, R.N., ${ }^{1}$ \\ Shufang Li, R.N., ${ }^{1}$ Zhaohui Wang, M.D., ${ }^{2}$ Shangming Huang, M.D., ${ }^{1}$ \\ Shaojuan Huang, R.N., ${ }^{1}$ Yingying Li, M.D., ${ }^{1}$ Jingli Chen, M.D., ${ }^{1}$ Mingfeng He, M.D. ${ }^{1 *}$ \\ ${ }^{1}$ Department of Critical Care and Emergency Medicine, Foshan Hospital of Traditional Chinese Medicine, Foshan-China \\ ${ }^{2}$ Department of Orthopedic Surgery, Foshan Hospital of Traditional Chinese Medicine, Foshan-China \\ ${ }^{\star}$ Zhixin Wu and Mingfeng He contributed equally and share the first authorship.
}

\begin{abstract}
BACKGROUND: Despite the magnitude of occupational hand injuries, there are no authoritative guidelines for hand injury prevention, and little research has been done to investigate the epidemiology of acute occupational hand injuries in South China or other developing areas. In this study, the epidemiology of acute occupational hand injuries treated in emergency departments (EDs) in Foshan City, South China, was examined and data were supplied to assist with preventive strategies in similar developing regions.

METHODS: A multicenter study was prospectively designed and conducted in 5 large hospital EDs in Foshan City from July 2010 to June 20I I. An anonymous questionnaire was designed specifically to collect the data for this study.

RESULTS: A total of 2142 patients with acute occupational hand injury completed the questionnaire within the I-year study period. Results indicated that most occupational hand injuries were caused by machinery. Hand injury type and site of the injury did not correspond to age, but were related to gender and job category. July and August 2010 were the peak periods of admission to EDs, while January and February 2010 were the trough periods.
\end{abstract}

CONCLUSION: Epidemiological data enhance our knowledge of acute occupational hand injuries and could play a role in the prevention and treatment of future occupational hand injuries.

Keywords: Emergency department; epidemiology; hand; occupational injury; trauma.

\section{INTRODUCTION}

Hand injuries are costly, and a major cause of morbidity in China and around the world. The incidence of occupational hand injury varies across different industries, ranging from 4 to II per 100 workers per year. Occupational hand injury is one of the top causes of lost days from work, and it imposes a great economic burden on the country. ${ }^{[1-6]}$ In the US, the annual cost of treating upper extremity disorders, including hand injuries, was over $\$ 18$ billion. ${ }^{[2]}$ The Center for Disease Control and Prevention reported that an estimated $30 \%$ of occupational injuries treated in US emergency departments (EDs) are hand injuries. ${ }^{[6]}$

However, very few papers have been published worldwide on the epidemiology of acute occupational hand injuries treated in the ED in China or other developing regions. Despite the magnitude of occupational hand injuries, there are no authoritative guidelines for hand injury prevention, and little research has been done to investigate the epidemiology of acute occupational hand injuries in South China.

Cite this article as: Wu Z, Guo Y, Gao J, Zhou J, Li S, Wang Z, et al. The epidemiology of acute occupational hand injuries treated in emergency departments in Foshan City, South China. Ulus Travma Acil Cerrahi Derg 2018;24:303-310.

Address for correspondence: Zhixin Wu, M.D.

D6\# Qinren Rd, Department of Critical Care and Emergency Medicine, Foshan Hospital of Traditional

Chinese Medicine, Foshan City 528000, Guangdong Province, China.

Tel: +086-135-289-96895 E-mail: seaguardsums@msn.com

Ulus Travma Acil Cerrahi Derg 2018;24(4):303-310 DOI: 10.5505/tjtes.2016.59020 Submitted: 27.10.2015 Accepted: 06.12.2016 Online: 19.06.2018

Copyright 2018 Turkish Association of Trauma and Emergency Surgery 
Foshan City is a major metropolis and typical developing area in South China with substantial industrial activity, and occupational hand injuries are the leading work-related injury. ${ }^{[7]}$ The purpose of this study was to identify the epidemiology of acute occupational hand injuries treated in EDs in Foshan City, South China, and to provide a series of hand injury prevention suggestions for similar developing areas.

\section{MATERIALS AND METHODS}

\section{Setting}

Foshan City is located in the mid-south of Guangdong Province, South China. It governs 5 districts: Chancheng, Nanhai, Shunde, Gaoming and Sanshui. The city covers a total area of $3848.49 \mathrm{~km}^{2}$ and has a population of at least 5.923 million, including $3.6 \mathrm{II}$ million registered permanent residents. The largest hospital EDs in each district are Foshan Hospital of Traditional Chinese Medicine (FSTCM), Foshan Nanhai District Hospital of Traditional Chinese Medicine, Shunde District Longjiang Hospital, Gaoming District People's Hospital and Sanshui District People's Hospital. Approximately 80,000 patients are assessed per year in each ED. A multicenter study was prospectively designed and conducted in these 5 large hospital EDs in the period between July 2010 and June $201 \mathrm{I}$.

\section{Patient Selection}

Study participants were those presenting to these hospital EDs with injuries to the fingers, hand, or wrist, including laceration, crush, avulsion, puncture, fracture, contusion, amputation, or dislocation. Informed verbal consent was obtained from eligible participants when they arrived at the ED. Some were unable to provide written consent at admission due to the nature of the injury; however, patients who agreed to participate in the study were provided with the relevant information and gave consent.

\section{Exclusion Criteria}

Patients who were younger than 14 years of age or who presented with hemodynamically unstable polytrauma were excluded from the study.

\section{Data Collection}

An anonymous questionnaire (Appendix I) was designed to collect data regarding background demographics, detailed exposure information, assessment of hand injury, and health insurance status. If the hand injury occurred at work, occupational information was recorded, including training record, mechanism of injury, and average salary. Twenty non-medical investigators received a 6-hour investigation training course. These investigators administered the questionnaire in the ED. The document was written in Chinese, in order to avoid misunderstanding.

\section{Ethical Approval}

All procedures performed in this study involving human participants were approved by the ethics committee of FSTCM and were conducted in accordance with the 1964 Helsinki Declaration and its later amendments or comparable ethical standards. Informed consent was obtained from all individual participants included in the study.

\section{Statistical Analyses}

Study data were entered into a Microsoft Excel (Microsoft Corp., Redmond, WA, USA) database and analyzed using SPSS for Windows, Version 13.0. (SPSS, Inc., Chicago, IL, USA). Descriptive statistics of mean and SD were provided for numerical variables, while categorical variables were given as frequency ( $n$ ) and percentage. Categorical variables were compared using chi-square test. Differences were considered statistically significant at a level of $p<0.05$.

\section{RESULTS}

\section{Demographics}

During the study period, there were 2186 Chinese patients with acute occupational hand injury assessed by physicians in an ED, of which 2142 (98\%) met the study criteria (mean age: $31.33 \pm$ I I.00 years, range: $|4-7|$ years; $81.56 \%$ male). They were divided into subgroups according to age, medical insurance status, job category, job tenure, education level, and other characteristics. In this study, I I 09 (5I.78\%) patients were between 25 and 44 years of age and 116 (5.42\%) patients were minors. Of the total, 1935 (90.34\%) had medical insurance, and $856(39.96 \%)$ patients had I to 3 years of job tenure. The education level of the majority was graduation from secondary school (I706; 79.64\%). The majority had an annual salary ranging from $\$ 3,000$ to $\$ 4,000$ (1006; 46.97\%). Most worked at a private business (196I; $91.54 \%)$. Only half of the patients (1076; 50.23\%) had safety training before beginning work, a mean of $84.74 \pm 39.51$ safety training hours. Employees had a mean of $4.1 \mathrm{I} \pm 0.35$ days of work training. When the hand injury occurred, they had been working mean of 5.06 I .04 hours without rest. For II 63 (54.30\%) patients, the interval from hand injury to ED arrival was less than 30 minutes. Emergency hand surgery was indicated for 1445 (67.46\%) patients on admission (Table I).

\section{Characteristics of Injuries}

Most occupational hand injuries were caused by machinery (2112; 99.6\%). The most common types of injury were caused by pressing and cutting machinery $(42.11 \%$ and $29.41 \%$, respectively). Most patients had finger injury (1760; 82.16\%). The most commonly injured fingers were the thumb, index, and middle finger, especially on the right hand. There were 26 study participants suffering from injuries to both hands. The hand injury type and the site of the injury were not related 
Table I. General characteristic of the study patients

\begin{tabular}{|c|c|c|}
\hline Characteristics & $\mathbf{n}$ & $\%$ \\
\hline \multicolumn{3}{|l|}{ Gender } \\
\hline Male & 1747 & 81.56 \\
\hline Female & 395 & 18.44 \\
\hline \multicolumn{3}{|l|}{ Age-group (years) } \\
\hline$<15$ & 8 & 0.37 \\
\hline $15-24$ & 726 & 33.89 \\
\hline $25-44$ & 1109 & 51.78 \\
\hline $45-64$ & 294 & 13.73 \\
\hline$\geq 65$ & 5 & 0.23 \\
\hline \multicolumn{3}{|l|}{ Health insurance } \\
\hline Social security insurance & 1935 & 90.34 \\
\hline None & 196 & 9.15 \\
\hline Other insurance & II & 0.51 \\
\hline \multicolumn{3}{|l|}{ Job category } \\
\hline Metal-machinery & 826 & 38.56 \\
\hline Food handling & 72 & 3.36 \\
\hline Maintenance/repair & 256 & 11.95 \\
\hline Wood work & 104 & 4.86 \\
\hline Construction & 104 & 4.86 \\
\hline Textile & 153 & 7.14 \\
\hline Printing & 73 & 3.41 \\
\hline Others & 554 & 25.86 \\
\hline \multicolumn{3}{|l|}{ Job tenure } \\
\hline$<1 \mathrm{yr}$ & 588 & 27.45 \\
\hline $\mathrm{I}-3 \mathrm{yr}$ & 856 & 39.96 \\
\hline$>3 \mathrm{yr}$ & 698 & 32.59 \\
\hline \multicolumn{3}{|l|}{ Experience of safety training } \\
\hline Yes & 1076 & 50.23 \\
\hline No & 1066 & 49.77 \\
\hline \multicolumn{3}{|l|}{ Education level } \\
\hline Illiterate & 25 & 1.17 \\
\hline Primary school & 314 & 14.66 \\
\hline Secondary school & 1706 & 79.64 \\
\hline Post-secondary and above & 97 & 4.53 \\
\hline \multicolumn{3}{|l|}{ Annual wage } \\
\hline$<\$ 2,000$ & 40 & 1.86 \\
\hline$\$ 2,000-\$ 3,000$ & 474 & 22.13 \\
\hline$\$ 3,000-\$ 4,000$ & 1006 & 46.97 \\
\hline$\$ 4,000-\$ 6,000$ & 492 & 22.97 \\
\hline$>\$ 6,000$ & 130 & 6.07 \\
\hline \multicolumn{3}{|l|}{ The nature of business } \\
\hline Private business & $196 \mid$ & 91.54 \\
\hline State-owned business & 73 & 3.41 \\
\hline Foreign-funded business & 25 & 1.17 \\
\hline \multicolumn{3}{|l|}{ The nature of business } \\
\hline Joint venture & 47 & 2.20 \\
\hline Other partnership & 20 & 0.93 \\
\hline Other & 16 & 0.75 \\
\hline
\end{tabular}

Table I. General characteristic of the study patients (cont.)

\begin{tabular}{lcc}
\hline Characteristics & $\mathbf{n}$ & $\%$ \\
\hline $\begin{array}{l}\text { Interval from the injury onset to ED arrival } \\
\quad<30 \mathrm{~min}\end{array}$ & 1163 & 54.30 \\
$30 \mathrm{~min}-60 \mathrm{~min}$ & 504 & 23.53 \\
$60 \mathrm{~min}-120 \mathrm{~min}$ & 262 & 12.23 \\
$\quad>120 \mathrm{~min}$ & 213 & 9.94 \\
Disposition & & \\
$\quad$ Discharge & 664 & 31.00 \\
$\quad$ Admission & 1445 & 67.46 \\
$\quad$ Transfer to another hospital & 29 & 1.35 \\
$\quad$ Discharge against medical advice & 4 & 0.19 \\
Total & 2142 & 100.00 \\
\hline ED: Emergency departments. & &
\end{tabular}

Table 2. Characteristics of occupational hand injuries

\begin{tabular}{|c|c|c|}
\hline Characteristics & $\mathbf{n}$ & $\%$ \\
\hline \multicolumn{3}{|l|}{ Type of injury $(n=2 \mid 42)$} \\
\hline Cutting & 630 & 29.41 \\
\hline Laceration & 35 & 1.64 \\
\hline Puncture & 101 & 4.72 \\
\hline Amputation & 157 & 7.33 \\
\hline Compression & 902 & 42.11 \\
\hline Contusion & 129 & 6.02 \\
\hline Crushing injury & 52 & 2.43 \\
\hline Fracture & 8 & 0.37 \\
\hline Burning & 20 & 0.93 \\
\hline Unknown mechanical equipment & 78 & 3.64 \\
\hline Non-machinel & 30 & 1.40 \\
\hline \multicolumn{3}{|l|}{ Injury site $(n=2 \mid 42)$} \\
\hline Wrist & 46 & 2.15 \\
\hline Hand & 191 & 8.92 \\
\hline Finger & 1760 & 82.16 \\
\hline Multiple & 145 & 6.77 \\
\hline \multicolumn{3}{|l|}{ Injury finger $(n=1855)$} \\
\hline Thumb & 427 & 23.02 \\
\hline Index & 515 & 27.76 \\
\hline Middle & 502 & 27.07 \\
\hline Ring & 143 & 7.7I \\
\hline Little & 213 & 11.48 \\
\hline Multiple & 55 & 2.96 \\
\hline \multicolumn{3}{|l|}{ Injury hand $(n=2 \mid 42)$} \\
\hline Right & 1146 & 53.50 \\
\hline Left & 970 & 45.29 \\
\hline Both & 26 & 1.21 \\
\hline
\end{tabular}

to age, but did correlate to gender and job category. In all, $80.52 \%$ of patients were wearing gloves when the injury occurred (Tables 2-4). 
Table 3. Comparison of injury site with demographic variables and job category

\begin{tabular}{|c|c|c|c|c|c|c|c|c|c|}
\hline \multirow[t]{3}{*}{ Variable } & \multicolumn{9}{|c|}{ Injury site } \\
\hline & \multicolumn{2}{|c|}{ Wrist $(n=46)$} & \multicolumn{2}{|c|}{ Hand $(n=|9|)$} & \multicolumn{2}{|c|}{ Finger $(n=1760)$} & \multicolumn{2}{|c|}{ Multiple $(n=145)$} & \multirow[t]{2}{*}{$\mathbf{p}$} \\
\hline & $\mathbf{n}$ & $\%$ & $\mathbf{n}$ & $\%$ & $\mathbf{n}$ & $\%$ & $\mathbf{n}$ & $\%$ & \\
\hline \multicolumn{10}{|l|}{ Gender } \\
\hline Male & 40 & 2.29 & 165 & 9.44 & 1422 & 81.40 & 120 & 6.87 & $<0.001$ \\
\hline Female & 6 & 1.52 & 26 & 6.58 & 338 & 85.57 & 25 & 6.33 & \\
\hline \multicolumn{10}{|l|}{ Age-group (years) } \\
\hline$<15$ & 0 & 0.00 & 0 & 0.00 & 7 & 87.50 & 1 & 12.50 & \\
\hline $15-24$ & 20 & 2.75 & 72 & 9.92 & 588 & 80.99 & 46 & 6.34 & \\
\hline $25-44$ & 16 & 1.44 & 96 & 8.66 & 925 & 83.41 & 72 & 6.49 & 0.406 \\
\hline $45-64$ & 10 & 3.40 & 23 & 7.82 & 236 & 80.27 & 25 & 8.51 & \\
\hline $65+$ & 0 & 0.00 & 0 & 0.00 & 4 & 80.00 & 1 & 20.00 & \\
\hline \multicolumn{10}{|l|}{ Health insurance } \\
\hline Social security insurance & 41 & 2.12 & 171 & 8.84 & 1599 & 82.63 & 124 & 6.41 & \\
\hline None & 5 & 2.55 & 20 & 10.20 & 153 & 78.06 & 18 & 9.19 & 0.082 \\
\hline Other & 0 & 0.00 & 0 & 0.00 & 8 & 72.73 & 3 & 27.27 & \\
\hline \multicolumn{10}{|l|}{ Job category } \\
\hline Metal-machinery & 15 & 1.82 & 75 & 9.08 & 692 & 83.78 & 44 & 5.32 & \\
\hline Food handling & 2 & 2.78 & 10 & 13.89 & 56 & 77.78 & 4 & 5.55 & \\
\hline Maintenance/repair & 1 & 0.39 & 27 & 10.55 & 218 & 85.15 & 10 & 3.91 & \\
\hline Wood work & 1 & 0.96 & 9 & 8.66 & 85 & 81.73 & 9 & 8.65 & 0.001 \\
\hline Construction & 5 & 4.81 & 12 & 11.54 & 73 & 70.19 & 14 & 13.46 & \\
\hline Textile & I & 0.65 & 4 & 2.61 & 138 & 90.20 & 10 & 6.54 & \\
\hline Printing & 1 & 1.37 & 6 & 8.22 & 62 & 84.93 & 4 & 5.48 & \\
\hline Others & 20 & 3.61 & 48 & 8.66 & 436 & 78.70 & 50 & 9.03 & \\
\hline
\end{tabular}

\section{Perceived Cause of Occupational Hand Injuries}

All of the patients were asked about the perceived cause of hand injury. "Distraction" was response selected by 1152 (53.78\%) participants, while 330 (15.41\%) selected "pure accident," and 257 (12.00\%) selected "no protection” (Table 5).

\section{Peak and Trough Periods in Admission to ED}

During the period of July 2010 to June 20II, July and August 2010 was the peak period of admission to the ED, while January and February 2010 was the trough period (Fig. I). There was no obvious peak period with respect to day of the week (Monday through Sunday) during the entire year (Fig. 2).

\section{DISCUSSION}

To the best of our knowledge, this is the first multicenter study to analyze and describe the epidemiology of acute occupational hand injuries in South China. There are no authoritative reports about the epidemiology of acute occupational hand injuries in China. Current occupational safety standards are inadequate, and many employers don't pay attention to safety management training for work-related tasks. Relevant laws need improvement to protect employees' rights. ${ }^{[7]}$ The present study provides useful information for the national health service and local labor department to use to develop strategies and decrease the risk of occupational hand injury. The social and economic impact of hand injury on society highlights the importance of prevention of these injuries. [7-10] Several studies have reported on the epidemiology and prevention of acute occupational hand injury in developed countries. ${ }^{[1-17]}$ In Chow's study, statistically significant associ-

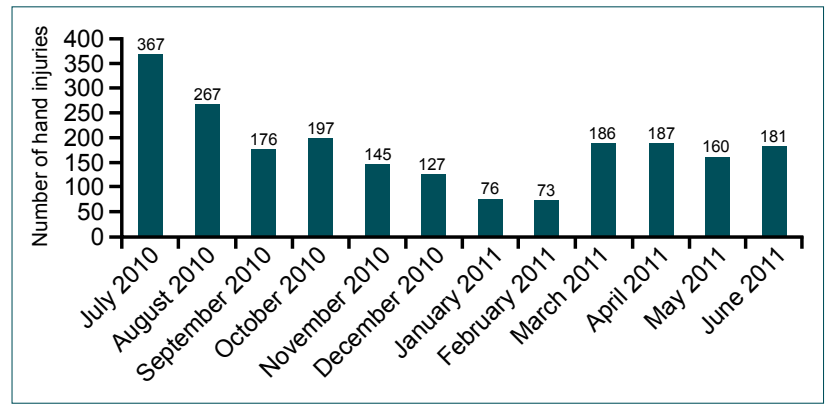

Figure 1. Distribution of occupational hand injuries by month. 
Table 4. Comparison of some injury types by sex, age group, and job category

\begin{tabular}{|c|c|c|c|c|c|c|c|c|c|c|c|c|c|}
\hline \multirow[t]{3}{*}{ Variable } & \multicolumn{13}{|c|}{ Injury type } \\
\hline & \multicolumn{2}{|c|}{$\begin{array}{l}\text { Cutting } \\
(n=630)\end{array}$} & \multicolumn{2}{|c|}{$\begin{array}{l}\text { Puncture } \\
(n=101)\end{array}$} & \multicolumn{2}{|c|}{$\begin{array}{c}\text { Amputation } \\
(n=157)\end{array}$} & \multicolumn{2}{|c|}{$\begin{array}{c}\text { Compression } \\
(n=902)\end{array}$} & \multicolumn{2}{|c|}{$\begin{array}{l}\text { Contusion } \\
(n=129)\end{array}$} & \multicolumn{2}{|c|}{$\begin{array}{c}\text { Other } \\
(n=223)\end{array}$} & \multirow[t]{2}{*}{$\mathbf{p}$} \\
\hline & $\mathbf{n}$ & $\%$ & $\mathbf{n}$ & $\%$ & $\mathbf{n}$ & $\%$ & $\mathbf{n}$ & $\%$ & $\mathbf{n}$ & $\%$ & $\mathbf{n}$ & $\%$ & \\
\hline \multicolumn{14}{|l|}{ Gender } \\
\hline Male & 533 & 30.51 & 63 & 3.61 & 138 & 7.90 & 726 & 41.56 & 107 & 6.12 & 180 & 10.30 & $<0.001$ \\
\hline Female & 97 & 24.55 & 38 & 9.62 & 19 & 4.81 & 176 & 44.56 & 22 & 5.57 & 43 & 10.89 & \\
\hline \multicolumn{14}{|l|}{ Age-group (years) } \\
\hline$<15$ & I & 12.50 & 0 & 0.00 & 1 & 12.50 & 5 & 62.50 & 0 & 0.00 & 1 & 12.50 & \\
\hline $15-24$ & 213 & 29.33 & 42 & 5.79 & 57 & 7.85 & 306 & 42.15 & 40 & 5.51 & 68 & 9.37 & \\
\hline $25-44$ & 322 & 29.04 & 53 & 4.78 & 73 & 6.58 & 468 & 42.20 & 71 & 6.40 & 122 & 11.00 & 0.706 \\
\hline $45-64$ & 91 & 30.95 & 6 & 2.04 & 26 & 8.84 & 121 & 41.16 & 18 & 6.12 & 32 & 10.89 & \\
\hline $65+$ & 3 & 60.00 & 0 & 0.00 & 0 & 0.00 & 2 & 40.00 & 0 & 0.00 & 0 & 0.00 & \\
\hline \multicolumn{14}{|l|}{ Health insurance } \\
\hline Social security insurance & 548 & 28.32 & 94 & 4.86 & 143 & 7.39 & 839 & 43.36 & 108 & 5.58 & 203 & 10.49 & \\
\hline None & 81 & 41.33 & 6 & 3.06 & 13 & 6.63 & 57 & 29.08 & 19 & 9.69 & 20 & 10.21 & $<0.001$ \\
\hline Other insurance & I & 9.09 & 1 & 9.09 & 1 & 9.09 & 6 & 54.55 & 2 & 18.18 & 0 & 0.00 & \\
\hline \multicolumn{14}{|l|}{ Job category } \\
\hline Metal-machinery & 202 & 24.45 & 30 & 3.63 & 82 & 9.93 & 381 & 46.13 & 41 & 4.96 & 90 & 10.90 & \\
\hline Food handling & 50 & 69.44 & 1 & 1.39 & I & 1.39 & 7 & 9.72 & I & 1.39 & 12 & 16.67 & \\
\hline Maintenance/repair & 65 & 25.39 & 4 & 1.56 & 11 & 4.29 & 123 & 48.05 & 24 & 9.38 & 29 & 11.33 & \\
\hline Wood work & 61 & 58.65 & 3 & 2.89 & 9 & 8.65 & 18 & 17.31 & 5 & 4.81 & 8 & 7.69 & \\
\hline Construction & 32 & 30.77 & 22 & 1.92 & 9 & 8.65 & 43 & 41.35 & 10 & 9.62 & 8 & 7.69 & $<0.001$ \\
\hline Textile & 31 & 20.26 & 37 & 24.18 & 10 & 6.54 & 53 & 34.64 & 10 & 6.54 & 12 & 7.84 & \\
\hline Printing & 19 & 26.03 & 3 & 4.11 & 4 & 5.48 & 39 & 53.42 & 2 & 2.74 & 6 & 8.22 & \\
\hline Others & 170 & 30.69 & 21 & 3.79 & 31 & 5.60 & 238 & 42.96 & 36 & 6.50 & 58 & 10.46 & \\
\hline
\end{tabular}

ations were found between the incidence of hand injury and exposure to these 7 factors: using malfunctioning equipment/ materials, using a different work method, performing an unusual task, working overtime, feeling ill, being distracted, and rushing. ${ }^{\left[{ }^{1}\right]}$ Whether the use of gloves can protect against hand

Table 5. Perceived cause of occupational hand injury

\begin{tabular}{lcc}
\hline Patient's idea of the cause & $\mathbf{n}$ & $\%$ \\
\hline Pure accident & 330 & 15.41 \\
No protection & 257 & 12.00 \\
Faulty machine & 47 & 2.19 \\
Distraction & 1152 & 53.78 \\
Unfamiliar with machine & 138 & 6.44 \\
Poor cooperation & 121 & 5.65 \\
Fatigue & 63 & 2.94 \\
No idea & 34 & 1.59 \\
Total & 2142 & 100 \\
\hline
\end{tabular}

injury is controversial. Schaub and Chung found that the use of gloves alone in industry has been reported to reduce the risk of hand injury by as much as $60 \%{ }^{\left[{ }^{11}\right]}$ However, Chow found that the use of gloves had insignificant protective effect on the incidence of hand injury. ${ }^{[1]}$ In $19 \%$ of the injuries that occurred while gloves were worn, they did not protect against mechanical energy transferred to the hand. Glove use may reduce the

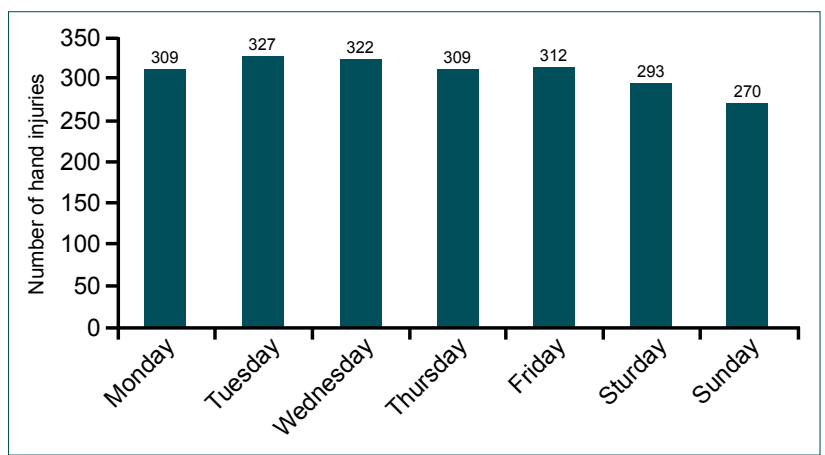

Figure 2. Distribution of occupational hand injuries by day of the week. 
risk of laceration and puncture injury, but not crush, fracture, avulsion, or amputation. ${ }^{[1,10]}$ In this study, $80.52 \%$ of the participants were wearing gloves when the hand injury occurred. According to several published articles, other factors found to influence occupational hand injury include using defective materials, presence of cardiovascular disease, extended work hours/lack of sleep, age of less than 25 years, smoking, regular consumption of alcohol, and long work hours. It has also been demonstrated that most occupational hand injuries occur in the morning, with a peak before lunchtime. ${ }^{[1, \mid 18-21]}$

In our study, most of the patients were young men. Most of the hand injuries were caused by machinery used for cutting and pressing. The treatment of hand injuries is often of long duration, and frequently results in variable but persistent disability. Injuries of this nature can preclude patients from returning to their previous occupation. ${ }^{[20]}$ Fortunately, most of the patients in this study had medical insurance guaranteed and supported by the government, and could access adequate medical treatment. ${ }^{[7]}$ However, some patients (9.15\%) had no medical insurance due to the economic burden it entails and did not understand the risks of being uninsured. They may have a heavy economic and psychological burden as a result of long-term prognosis of hand injury. In China, some private businesses disobey the law and do not provide any kind of insurance to employees in order to reduce costs. Most of the patients in this study had achieved secondary school education level $(79.64 \%)$ and were qualified for their job. Most (72.55\%) had work experience of more than I year. However, half of participants lacked safety training, which has been shown to be a potential risk factor for occupational hand injury. ${ }^{[10]}$ Most had lower annual wage compared with average income in South China.

As we know, Foshan City is an advanced industrial city with thousands of labor-intensive industrial factories, and is representative of developing areas in China. ${ }^{[7]}$ Tens of thousands of employees are working on the production assembly line every day. Their jobs are repetitive: performing the same manufacturing process again and again. It's very easy, but boring. Most factories have instituted a series of management programs to improve production efficiency. Workers have limited time for rest. In our study, subjects had been working mean of $5.06 \pm 1.04$ hours without rest when the hand injury occurred. The main cause of injury was "distraction," according to $53.78 \%$ of participants. In this I-year study period, July and August 2010 were the peak period for admissions to EDs. In Foshan City, most factories are very busy with rush production orders during these 2 months. January and February were trough periods in number of admissions to EDs, due to the Spring Festival holiday. July and August are also the months when the weather is hottest in South China. However, few factories have air-conditioners or adequate fans to cool the work environment. In this uncomfortable situation, workers may be more prone to "distraction" than in other months and make mistakes.
Based on the results of our study, we suggest the following: First, all businesses must provide basic medical insurance for their employees, according to the national law. In China, there is a compulsory social security insurance law. Second, we noticed that about $5.42 \%$ of patients in the study were minors. The law prohibits any business from employing workers younger than 16 years of age in China. It is necessary for the national health service and local labor department to improve supervision and see that all businesses strictly follow the law. Third, safety training needs to be emphasized. All workers should regularly complete a series of safety training and education courses. The national health service and local labor department should provide authoritative guidelines for education and create risk assessment tools for occupational safety to identify potential hazards in the workplace. Fourth, business managers should improve the work environment, including providing a work-rest schedule and decreasing rush production orders. Fifth, the country should encourage enterprises to improve technologies and engineering safety devices to further reduce the risk of occupational trauma. The country should also authoritatively publish a series of recommendations on safeguards, design, and proper use of various machines and protective equipment that meet the standards for anticipated hazards.

Our study has some limitations. We analyzed patients with occupational hand injuries treated in EDs, which underestimates the actual incidence of such injuries, since some subjects do not present to an ED. An anonymous questionnaire was designed for collection of study data, and thus, the investigators could not recognize a participant who returned to the ED due to reoccurrence. Patients who visited the ED on multiple occasions for hand injury may have been included in this study. This topic needs further research.

\section{Conclusion}

Epidemiological data enhances our knowledge of acute occupational hand injuries and may play a role in the prevention and treatment of future occupational hand injuries, with the end result of reducing lost work time and economic burden.

\section{Acknowledgements}

We thank Paula Brazil, M.A. (Arizona Department of Health Services, 150 North $18^{\text {th }}$ Avenue, Suite 540, Phoenix, AZ 85007, USA) for her assistance with this manuscript. We also thank Mrs. Deng Huiru (Shunde District Longjiang Hospital), Mrs. Guan Weiqun (Gaoming District People's Hospital), Mrs. Huang Xuelan (Sanshui District People's Hospital), Mrs. Chen Xiaomei (Nanhai District TCM Hospital) and Mrs. Liu Yanghui (Chancheng District Foshan Hospital of TCM) for their research work for this study.

\section{Funding Sources}

Funding for this study was provided by the Internal Grants 
from Science and Technology Foundation of Foshan City, China (no. 20I4AG10005) and the Municipal Clinical Key Specialty Construction Project Funds of Foshan City (No. Fspy2-20I5004 and No.FSGSPZDI350I8).

\section{Conflict of interest: None declared.}

\section{REFERENCES}

1. Chow CY, Lee H, Lau J, Yu IT. Transient risk factors for acute traumatic hand injuries: a case-crossover study in Hong Kong. Occup Environ Med 2007;64:47-52. [CrossRef]

2. Dias JJ, Garcia-Elias M. Hand injury costs. Injury 2006;37:1071-7.

3. Rosberg HE, Carlsson KS, Cederlund RI, Ramel E, Dahlin LB. Costs and outcome for serious hand and arm injuries during the first year after trauma - a prospective study. BMC Public Health 2013;13:501. [CrossRef]

4. Kingston GA, Judd J, Gray MA. The experience of medical and rehabilitation intervention for traumatic hand injuries in rural and remote North Queensland: a qualitative study. Disabil Rehabil 2015;37:423-9. [CrossRef]

5. Leixnering M, Quadlbauer S, Szolarcz C, Schenk C, Leixnering S, Körpert K. Prevention of hand injuries - current situation in Europe. Handchir Mikrochir Plast Chir 2013;45:339-43.

6. Centers for Disease Control and Prevention (CDC). Nonfatal occupational injuries and illnesses among workers treated in hospital emergency departments--United States, 2003. MMWR Morb Mortal Wkly Rep 2006;55:449-52.

7. Huang SJ, Li SF,Ke YH. Epidemiological survey of patients with traumatic hand injury in emergency department. Journal of Nursing(China) 2011;18:23-5.

8. Kaya Bicer E, Kucuk L, Kececi B, Murat Ozturk A, Cetinkaya S, Ozdemir $\mathrm{O}$, et al. Evaluation of the risk factors for acute occupational hand injuries. Chir Main 2011;30:340-4. [CrossRef]

9. Sorock GS, Lombardi DA, Hauser RB, Eisen EA, Herrick RF, Mittleman MA. A case-crossover study of occupational traumatic hand injury: methods and initial findings. Am J Ind Med 2001;39:171-9. [CrossRef]

10. Sorock GS, Lombardi DA, Hauser R, Eisen EA, Herrick RF, Mittleman MA. A case-crossover study of transient risk factors for acute occupational hand injury. Occup Environ Med 2004;61:305-11. [CrossRef]

11. Schaub TA, Chung KC. Systems of provision and delivery of hand care, and its impact on the community. Injury 2006;37:1066-70. [CrossRef]

12. de Jong JP, Nguyen JT, Sonnema AJ, Nguyen EC, Amadio PC, Moran SL. The incidence of acute traumatic tendon injuries in the hand and wrist: a 10-year population-based study. Clin Orthop Surg 2014;6:196-202.

13. Ootes D, Lambers KT, Ring DC. The epidemiology of upper extremity injuries presenting to the emergency department in the United States. Hand (N Y) 2012;7:18-22. [CrossRef]

14. Panagopoulou P, Antonopoulos CN, Dessypris N, Kanavidis P, Michelakos T, Petridou ET. Epidemiological patterns and preventability of traumatic hand amputations among adults in Greece. Injury 2013;44:475-80. [CrossRef]

15. Hey HW, Seet CM. Hand injuries seen at an emergency department in Singapore. Eur J Emerg Med 2010;17:343-5. [CrossRef]

16. Serinken M, Karcioglu O, Sener S. Occupational hand injuries treated at a tertiary care facility in western Turkey. Ind Health 2008;46:239-46

17. Larsen CF, Mulder S, Johansen AM, Stam C. The epidemiology of hand injuries in The Netherlands and Denmark. Eur J Epidemiol 2004;19:323-7. [CrossRef]

18. Chung KC. Volunteering in the developing world: The 2003-2004 Sterling Bunnell Traveling Fellowship to Honduras and Cambodia. J Hand Surg Am 2004;29:987-93. [CrossRef]

19. Lombardi DA, Sorock GS, Hauser R, Nasca PC, Eisen EA, Herrick RF, et al. Temporal factors and the prevalence of transient exposures at the time of an occupational traumatic hand injury. J Occup Environ Med 2003;45:832-40. [CrossRef]

20. Trybus M, Lorkowski J, Brongel L, Hladki W. Causes and consequences of hand injuries. Am J Surg 2006;192:52-7. [CrossRef]

21. Garg R, Cheung JP, Fung BK, Ip WY. Epidemiology of occupational hand injury in Hong Kong. Hong Kong Med J 2012;18:131-6.

\section{ORIJINAL ÇALIŞMA - ÖZET}

\section{Güney Çin Foshan ilinde acil servislerde tedavi edilen mesleksel akut el yaralanmalarının epidemiyolojisi}

Dr. Zhixin Wu, ${ }^{1}$ Dr. Yueming Guo, ${ }^{2}$ Dr. Junqing Gao, ${ }^{2}$ Dr. Jianyi Zhou, ${ }^{1}$ Dr. Shufang Li, ${ }^{1}$ Dr. Zhaohui Wang, ${ }^{2}$ Dr. Shangming Huang, ${ }^{1}$ Dr. Shaojuan Huang, ${ }^{1}$ Dr. Yingying Li, ${ }^{1}$ Dr. Jingli Chen, ${ }^{1}$ Dr. Mingfeng He ${ }^{1}$

${ }^{1}$ Geleneksel Çin Tıbbı Foshan Hastanesi, Tıbbi Bakım ve Acil Tıp Bölümü, Foshan-Çin Halk Cumhuriyeti

${ }^{2}$ Geleneksel Çin Tıbbı Foshan Hastanesi, Ortopedik Cerrahi Bölümü, Foshan-Çin Halk Cumhuriyeti

AMAÇ: Mesleksel el yaralanmalarının kapsamına rağmen el yaralanmalarını korunmasına ilişkin yetkin kılavuzlar mevcut olmadığı gibi Güney Çin veya diğer gelişmekte olan alanlarda akut mesleksel el yaralanmalarının epidemiyolojisi az sayıda çalışmada araştııımıştır. Bu çalışmada Güney Çin Foshan ilindeki acil servislerde tedavi edilmiş akut mesleksel el yaralanmalarının epidemiyolojisini araştırdık ve gelişmekte olan benzer alanlarda koruyucu stratejilere ilişkin veriler sağladık.

GEREÇ VE YÖNTEM: Foshan ilinde beş büyük hastanenin acil bölümlerinde ileriye yönelik ve çok merkezli çalışma tasarlanıp yürütüldü. Bu çalışmada verileri toplamak için özellikle tasarlanmış bir adsız anket formu kullanıldı.

BULGULAR: Akut mesleksel el yaralanması olan toplam 2 I 42 denek bir yıllık çalışma dönemi içinde anket formlarını doldurmuştur. Mesleksel el yaralanmalarının çoğuna makineler neden olmuştu. El yaralanmasının tipi ve yaralanmanın yeri yaş farklılıklarıyla değil cinsiyet ve işin kategorisiyle ilişkiliydi. Acil servislere en çok Temmuz ve Ağustos 2010 aylarında en az Ocak ve Şubat 2010 aylarında hasta kabulü olmuştur.

TARTIŞMA: Epidemiyolojik veriler akut mesleksel el yaralanmalara ait bilgimizi artırmakta ve gelecekte mesleksel el yaralanmalarının engellenmesi ve tedavisinde rol oynayabilir.

Anahtar sözcükler: Acil bölüm; el; epidemiyoloji; mesleksel yaralanma; travma.

Ulus Travma Acil Cerrahi Derg 2018;24(4):303-310 doi: 10.5505/tjtes.2016.59020 


\section{Appendix I.}

\section{Acute Hand Injury Questionnaire - Foshan City}

No:

Gender:

Age:

I. Date of injury:

Day of the week:

Interval from the hand injury to Emergency Department arrival: minutes

$\square$ Disposition:
A. Treatment and release
B. Admission
C. Transfer to another hospital
D. Discharge against medical advice

2. Cause of injury:
A. Traffic accident
B. Activity of daily life
C. Injured by other people
D. Self-injury

E. Occupational injury

F. Other

3. Place of injury:
A. At work
B. At home
C. On streets or roads
D. Sports venue
E. Other

4. Place of work (District):
A. Chancheng
B. Shunde
C. Nanhai
D. Gaoming
E. Sanshu
F. Other

5. Was the patient treated at another hospital?
A. Yes
B. No

6. Handedness:
A. Left-handed
B. Right-handed
C. Both

7. Injured hand:
A. Left
B. Right

8. Type of injury:
A. Crush
B. Cut
C. Laceration
D. Contusion
E. Other specified (puncture, tear, strain, fracture, burn, compression, amputation)
F. Other unspecified

9. Injury site:
A. Wrist
B. Hand
C. Finger (Multiple choice)

10. Injured finger(s):
A. Thumb
B. Index
C. Long
D. Ring
E. Little (Multiple choice)

ป II. Education level:
A. Illiterate
B. Primary school
C. Secondary school
D. Post-secondary and above

12. Social security:
A. Medical insurance
B. None
C. Other

I3. If the injury is occupational hand injury:

$\square$ I. Job category:
A. Metal-machinery
B. Food handling
C. Maintenance/repair
D. Woodwork
E. Construction
F. Textiles
G. Printing
H. Other:
2. Cause of injury:
A. Pure accident
B. No protection
C. Faulty machine
D. Distraction
E. Unfamiliar with machine
F. Poor cooperation
G. Fatigue
H. No idea (Multiple choice)

3. Safety training:
A. Yes - Training hours:
B. No

4. When the hand injury occurred, patient had been working hours

ป 5 . Work experience: years

6. Nature of enterprise:
A. Private
B. State-owned
C. Foreign-funded
D. Joint-venture
E. Other partnership
F. Other
$\square$ 7. Annual salary:
A. $<\$ 2,000$
B. $\$ 2,000-\$ 3,000$
C. $\$ 3,000-\$ 4,000$
D. $\$ 4,000-\$ 6,000$ 